Article

\title{
Nordic Administrative Collaboration: Scope, Predictors and Effects on Policy Design and Administrative Reform Measures
}

\author{
Per Lægreid and Lise H. Rykkja* \\ Department of Administration and Organization Theory, University of Bergen, 5007 Bergen, Norway; \\ E-Mails: per.lagreid@uib.no (P.L.), lise.rykkja@uib.no (L.H.R.) \\ * Corresponding author
}

Submitted: 25 May 2020 | Accepted: 30 June 2020 | Published: 3 November 2020

\begin{abstract}
This article examines whether Nordic administrative collaboration is still 'alive and kicking,' or whether it has been marginalized by increased integration into Europe and strong international reform trajectories. We analyse the scope and intensity of Nordic administrative collaboration from a structural perspective based on the perceptions of civil servants in the Norwegian central government. We also address the implications of Nordic collaboration for policy design and reform measures. The main conclusion is that Nordic administrative collaboration can best be described as differentiated integration. The scope of Nordic administrative collaboration is rather broad, and its internal structural features vary significantly. Nordic collaboration is perceived to have more of an effect on policy design than on specific administrative reform means and measures. However, structural features also matter.
\end{abstract}

\section{Keywords}

administrative collaboration; administrative reforms; civil service; differentiated integration; Nordic countries; Norway; policy design; public policy

\section{Issue}

This article is part of the issue "Rediscovering Nordic Cooperation" edited by Anne Elizabeth Stie (University of Agder, Norway) and Jarle Trondal (University of Agder, Norway/ARENA University of Oslo, Norway).

(C) 2020 by the authors; licensee Cogitatio (Lisbon, Portugal). This article is licensed under a Creative Commons Attribution 4.0 International License (CC BY).

\section{Introduction}

In the EU literature there is a debate about the rise of a European administrative space resulting from increased European integration as the EU grows and develops (Olsen, 2003; Trondal \& Peters, 2013). This literature addresses the convergence of administrative systems and policies and emphasizes the spread of common administrative traditions (Knill, 2001; Meyer-Sahling \& Yesilkagit, 2011), public management practices (Christensen \& Lægreid, 2007) and coordination of EU policy at the national level (Kassim, Wright, \& Peters, 2000).

In the Nordic countries, the development of a common 'Nordic administrative space' has a long history. Nordic parliamentary collaboration goes back to 1952 when the Nordic Council was established. On the gov- ernment side, the Nordic Council of Ministers was set up in 1971 with a secretariat in Copenhagen. In each country there is a minister for Nordic cooperation and a Nordic Committee for Cooperation, which coordinates the day-to-day work of Nordic intergovernmental cooperation. This article examines collaboration at the administrative level as experienced by civil servants in the central government.

One interesting question is what effects the Nordic countries' joining the EU at various times and with different forms of affiliation have had on the Nordic administrative space (Jacobsson, Lægreid, \& Pedersen, 2004). Denmark joined the EU in 1972, Sweden and Finland became members in 1995, and Norway and Iceland received associate status through the European Area Agreement, also in 1995. Research on this topic 
to date has identified an effect of increased integration into Europe on administrative policy in the Nordic countries. Norwegian national coordination of EU policy has to a large extent copied the Danish model (Jacobsson et al., 2004). The Nordic countries' establishment of semi-independent regulatory agencies, the reorganization of integrated organizations into single-purpose organizations, corporatization, contracting out and privatizing service production all resonate with the liberal market principles of the EU. Another external factor affecting Nordic administrative collaboration stemmed from the New Public Management (NPM) reform trajectory that addressed managerialism, which had its origins in the OECD but came to the Nordic countries largely via certain EU member states. Later this was superseded by postNPM reform trends, which introduced more horizontal coordination of government organizations and efforts to enhance coordination between governments and other actors (Christensen \& Lægreid, 2007).

The question is whether Nordic administrative collaboration is still 'alive and kicking,' or whether it has become marginalized by these forces. Have we seen a process of disintegration (Olsen \& Sverdrup, 1998) or has integration simply become more differentiated between different Nordic countries, and different policy areas and institutions, with countries integrating to a different extent, at different times and at different speeds (Leruth, Gänzle, \& Trondal, 2019; Schimmelfenning, Leuffen, \& Ritterberger, 2015)?

This article addresses the scope and intensity of Nordic administrative collaboration, especially as seen by Norwegian central government actors. The article aims to answer three research questions by applying a structural perspective. The first question is a descriptive one, while the other two are explanatory. First, what is the scope of Nordic collaboration among Norwegian civil servants, measured by a) participation in Nordic committees or working groups and b) contact with Nordic governmental collaboration bodies? Second, to what degree can structural features, such as administrative level, position, and main tasks, explain the variation in Nordic collaboration among Norwegian civil servants? Third, what are the effects-as perceived by Norwegian civil servants-of Nordic collaboration on policy design and administrative reform measures?

To answer these questions, we use the findings from an extensive survey of civil servants in Norwegian ministries and central agencies conducted in 2016. We also draw on secondary sources analysing change and stability in Norwegian central government (Christensen, Egeberg, Lægreid, \& Trondal, 2018), Nordic collaboration (Jacobsson et al., 2001, 2004; Jacobsson \& Sundstrøm, 2020; Lægreid \& Pedersen, 1994), and Nordic administrative reforms (Greve, Ejersbo, Lægreid, \& Rykkja, 2019; Greve, Lægreid, \& Rykkja, 2016, 2018). Other sources include relevant public documents such as several reports from the Norwegian Agency of Public Management and information from managers in this agency as well as in the Department of ICT and Administrative Policy in the Norwegian Ministry of Local Government and Modernization.

In the following, we first give an account of current Nordic administrative reforms and collaboration. Second, we present the theoretical basis of our analysis, including hypotheses about variations in the scope and intensity of Nordic collaboration and the perceived effects of this collaboration on policy design and reform measures. Third, we specify our data sources. Fourth, we describe the scope of Nordic collaboration among civil servants in ministries and central agencies and look at how that scope varies according to structural factors. Fifth, we examine how the civil servants perceive the effects of Nordic collaboration on policy design and administrative reform efforts in their own field of work. Sixth, we analyse the differences in Nordic collaboration and in the perceived effects based on the theoretical perspective and draw some conclusions.

\section{Nordic Administrative Reform: An Adaptive and Agile Trajectory}

The tradition of close collaboration and of drawing inspiration from other Nordic countries when launching new public policy and administrative reform initiatives is long (Lægreid \& Pedersen, 1994). Even if there are differences between the Nordic countries in public policy and administrative reforms, there are also significant similaritiesfirst and foremost the fact that they are all modernizers (Bjurstrøm \& Christensen, 2017; Greve et al., 2016). According to Knutsen (2017), the Nordic model has been challenged, but is still viable. There are several Nordic models and the relationship between them is not very clear. Moreover, there is a combination of old traditions persisting and new forms of distinctiveness.

When the international performance management system was introduced in the Nordic countries it was largely adapted to fit the existing national administrative context (Kristiansen, 2015). The Nordic performance management style is characterized by bottom-up negotiation processes regarding goals and targets. It is primarily soft and dialogue-based, and performance information is only loosely coupled to sanctions (Christensen \& Lægreid, in press; Johnsen \& Vakkuri, 2006; Lægreid, Roness, \& Rubecksen, 2006). Furthermore, the Nordic countries seem to be able to combine a public administration that values professionalism and a public service ethos with a substantial effort to introduce managerial tools (Hammerschmid, Stimac, \& Wegrich, 2014). The managerial reforms have also been supplemented by reforms based on e-government, transparency, citizens' engagement, and coordination, reflecting a post-NPM reform trajectory.

It is, however, not very easy to link these reform trends directly to NPM or post-NPM in the Nordic countries. For example, agencification has a long history, and numerous relatively independent agencies were estab- 
lished pre-NPM. In addition, the Nordic countries were frontrunners regarding transparency long before postNPM reforms became a main trend (Greve et al., 2016). Hansen (2011) has revealed that there are similarities as well as differences regarding the adaptation of various reform measures in Denmark, Norway, and Sweden. Taken together, the reform trends can be seen as both constrained and enabled by national administrative traditions. At the same time, these administrative traditions might also change as a result of more contemporary administrative reforms.

A large-scale survey of top public-sector administrative executives in central government ministries and agencies in nineteen European countries provides insight into the specific administrative traditions and reforms of the Nordic countries. The survey was conducted in the period 2011-2014 and the Nordic respondents comprised 1,907 top civil servants in ministries and central agencies from Norway, Sweden, Denmark, Finland, and Iceland. The overall response rate for the Nordic countries was 35\% (Greve et al., 2016). The survey shows that managerial tools are common in the Nordic countries and that managerial role perceptions focusing on efficiency are rather strong (Greve et al., 2016). Overall, measures designed to improve the internal management of the administrative apparatus are used more widely than privatization and marketization. Management by objectives and results is widespread, for example.

According to the survey, traditional bureaucratic features, such as specialization by purpose or tasks and hierarchy, are still very much present in the Nordic countries. However, such hierarchical coordination and governance is less common than in many other European countries (Lægreid, Randma-Liiv, Rykkja, \& Sarapuu, 2016; Wegrich \& Stimac, 2014). The internal administrative hierarchy is rather weak compared with the rest of Europe. The use of collegial network arrangements, such as ad hoc, cross-cutting horizontal working groups, is common, according to the executives working in central government, but they are mainly set up as supplementary coordination arrangements. At the same time, the quality of vertical coordination within individual policy areas is seen as rather high in the Nordic countries. Horizontal coordination across policy areas is, on the other hand, perceived as weaker, but nevertheless better than in other European countries (Lægreid et al., 2016). A combination of high managerial autonomy and weak politicization is also a common feature in the Nordic countries compared with the rest of Europe.

The survey showed that Norwegian administrative executives tend to have a more positive view of reforms, seeing them as more consistent, comprehensive, and substantial than the average (Lægreid \& Rykkja, 2016). They were also seen as more bottom up, less contested by unions, more open to public involvement, and more about improving service delivery quality than about cost reductions and downsizing. The Norwegian executives saw collaboration and cooperation as an important re- form trend and reported that policy coherence and coordination had improved in recent years. Reforms in Norway were, moreover, seen as rather successful overall and as having resulted in improvements rather than in deterioration.

In general, executives in the Nordic countries rated public administration performance as higher than in other European countries. Thus, when the survey was conducted the situation was generally felt to have improved regarding issues such as efficiency, trust, staff motivation, service quality, and transparency (Greve et al., 2016). Overall, the Nordic countries were characterized by a high level of reform activity with substantial public involvement, and the effects of the reforms were judged positively. The Nordic model therefore emerges as one that is agile and adaptive, where new reform elements are rather effortlessly incorporated into the existing Nordic welfare state model (Greve et al., 2019).

The Nordic countries can be seen as rather eager reformers (Greve et al., 2018). However, there is not one dominant reform trajectory but rather a layering process going on, resulting in a hybrid and mixed system characterized by a complex administrative culture (Lægreid, 2017). The Nordic administrative tradition is therefore more multi-functional, representing a mixed model that includes partly conflicting values and cultures and hence produces tensions and trade-offs (Ejersbo, Greve, Lægreid, \& Rykkja, 2017). The Nordic countries have been affected by their increased integration into Europe as well as by the NPM reform movement, but there are also differences between them. For example, when looking at how the Nordic countries managed the COVID-19 crisis, a traditional difference between Sweden and the other Nordic countries appeared still to be relevant (Christensen \& Lægreid, 2020). Sweden is characterized by a collegial type of governmental decision-making and lacks formal individual ministerial power over the central agencies, while the other Nordic countries' espousal of the principle of ministerial responsibility allows a higher degree of individual steering of central agencies (Öberg \& Wockelberg, 2016).

The Nordic countries are dynamic in incorporating new external reform elements into the public sector, fitting what Streeck and Thelen (2005) identify as incremental institutional change. Reforms seem to have become a routine activity, and one set of reforms generally tends to generate new, related reforms (Brunsson \& Olsen, 1993). The administrative apparatus consists of rather composite institutional arrangements including partly competing views of how the public administration should be organized and structured. One reform idea is not simply swept away by another. The reform trends are complementary and supplementary rather than alternative. This results in a layered and hybrid Nordic administrative reform model in which new reform elements are added to existing ones.

The Nordic countries have been influenced by various governance ideas and display a modernized manage- 
rial and performance management perspective on public sector reform, coupled with participation and consultation in the reform process, increasing collaboration via network arrangements, and a continued emphasis on transparency. In this respect, the Nordic countries to some extent represent Neo-Weberian states, according to Pollitt and Bouckaert (2017). The overall reform narrative is one of modernization, with a combination of management, performance management, decentralization, whole-of-government coordination in networks, and transparency. The Nordic model thus emerges as a mixed system (Olsen, 2010) combining professional governance, stakeholder engagement, legality, and the more traditional Weberian bureaucratic principles, with a limited dose of market-based governance. Overall, the reforms are more system-maintaining than systemtransforming, characterized by pragmatism and transformation in slow motion. At the same time, the organizational structure of the public sector is rather complex. Years of continuing reform efforts mean that the public sector is still in a state of transformation.

Although similarities between the Nordic countries stand out in many respects, there are also some divergent perceptions of reform processes, trends, and content among Nordic executives (Greve et al., 2019). Sweden is in some respects a deviant case, scoring low on the perceived importance of digital governance and high on economic management tools, such as decentralized financial and staff decisions and performance management. Bjurstrøm and Christensen (2017) find that Sweden has taken a more radical NPM path, as illustrated, for instance by the privatization of public schools (Bjørklund, Clark, Edin, Fredriksson, \& Krueger, 2005) and by a general trend towards marketization (Sundstrøm, 2015).

In the executive survey analyzed by Greve et al. (2016), Iceland stood out with a high score on crisisdriven reforms and relatively low public involvement. Icelandic executives saw the reforms as being rather contested by the unions and as focusing on cost-cutting and downsizing. Norway displayed the opposite pattern on these two survey questions. Different from Sweden, the executives from Finland and Denmark perceived the reforms as being more bureaucrat-driven, more contested by the unions, and as characterized by rather little public involvement. These reform nuances in the Nordic countries may be connected to different domestic contexts, management styles and administrative traditions.

Nordic civil servants meet annually in a longstanding, permanent Nordic forum for administrative policy. Here the participants exchange information about what is on the administrative reform agenda in the different countries. Participants in the forum contend that the Nordic countries face similar challenges, but often at different times. There are many examples of Nordic countries' looking to one another for inspiration and role models, but few of these examples involve one country directly copying another. Similar solutions for open government, trust-based reform initiatives, efforts to reduce red tape, sector analyses, and evaluations are some initiatives that can be seen as being mutually inspired. In recent years, Norway has been inspired by reforms taking place in Denmark, for example. This is illustrated by the establishment of the Norwegian Digitalization Agency and the Agency for Administration and Economic Management as well as new initiatives within the fields of public sector innovation, digitalization, ethical guidelines, management codes of conduct, and leadership development. In Norway, the regulations for good management are inspired by the Danish Leadership Pipeline Institute. In addition, the introduction of an Innovation Barometer and a Digital Mailbox in Norway was inspired by similar arrangements in Denmark.

Administrative reforms in Norway are often launched after similar reforms have been implemented in other Nordic countries. Recent examples are the region and municipality reform and the police reform (Christensen, Lægreid, \& Rykkja, 2018). The reform of higher education, reforms related to immigration, transport infrastructure, the organization of the consumer apparatus, and climate change and sustainable development also have similar features. Some Norwegian reforms, such as the hospital reform and the reform of the welfare administration, have also inspired similar reforms in other Nordic countries. Thus, Nordic countries find inspiration for administrative policy and reforms in neighbouring countries.

A survey of Swedish ministries and central agencies in 2019 showed that after 20 years of EU membership Nordic collaboration was still as strong as it was before Sweden joined the EU (Jacobsson \& Sundstrøm, 2020). It concluded that Nordic administrative collaboration in Swedish central government was stronger than ever and seemed to have become more important the more Sweden became integrated into European collaboration.

Although the rhetoric surrounding public sector reforms is very similar in all the Nordic countries, there are more differences across countries when it comes to the use of specific reform means and measures, producing both converging and diverging practices as, for example, in the field of educational evaluation (Hansen, 2010). In the area of higher education, similar goals are pursued through different organizational arrangements (Bleiklie \& Michelsen, 2019). Also, in the area of evidence-based policymaking (Elvbakken \& Hansen, 2019), education policy (Helgøy \& Homme, 2007), and food safety regulation (Elvbakken, Lægreid, \& Rykkja, 2008), the Nordic countries all share the same basic ideas, but they are implemented in specific organizational settings and national contexts and therefore vary.

Overall European and international reform trajectories influence the Nordic countries. However, national filters lead to reform lags and variations, which impacts on the reforms (Christensen, Gornitzka, \& Maassen, 2014). The reform trajectories are both constrained and enabled by specific national cultural and structural contexts. Summing up, the Nordic administrative tradition can be 
seen as a mixed model that includes partly conflicting values that produce tension and trade-offs. This may have changed over time, and there are certainly differences between the Nordic countries, despite many similarities (Lægreid, 2017).

\section{An Administrative Structural Approach}

We examine the differentiated integration of the Nordic countries as an administrative phenomenon, seen from an organizational and public administration point of view as a system of interconnected ministries and central agencies (Bauer \& Trondal, 2015; Egeberg \& Trondal, 2018; March \& Olsen, 1989; Olsen, 2010). More specifically, we apply a structural perspective to examine the scope of Nordic collaboration and its perceived effects on policy design and administrative reforms in the Norwegian central civil service. The structural perspective underlines that the structural context of civil servants, meaning where they are situated in the formal organizational structure as well as their external network participation and contact patterns will influence their perceptions and behaviour as civil servants (Christensen, Lægreid, \& Røvik, 2020; Egeberg, 2012; Egeberg \& Trondal, 2018; Simon, 1958).

Our approach underlines that the structural context of civil servants will influence the scope of Nordic collaboration, how they perceive other countries as role models for their policy design, and the significance of different administrative reform measures in their daily work. Thus, Nordic collaboration through integration in network structures is first treated as a dependent variable, affected by where civil servants are located in the internal administrative organization, and then as an independent variable that may affect policy design and the perceived significance of administrative reform measures.

The main expectations are first, that the scope and intensity of Nordic collaboration will vary according to how relevant these tools are for different civil servants in their structural positions and related to their main tasks. Second, that their Nordic access structure, related to their contact and participation patterns, together with structural variables will have different effects on the use of international role models in policy design as well as on the perceived significance of different reform measures (Figure 1).
First, 'administrative level' differentiates between civil servants working in ministries and those in subordinate agencies. Civil servants working in ministries will be expected to score higher on participation and contact with Nordic bodies than those in the agencies because they are higher up in the hierarchy. Concerning the effects of administrative level on policy design and administrative reform tools, civil servants working in ministries will be expected to see more significant effects since they are situated at a higher level in the hierarchy and thus are more involved in policy design and administrative reforms.

The second structural variable is 'formal position' in the civil service hierarchy. The general assumption is that the hierarchical level at which civil servants work will differentiate the Nordic collaboration pattern and its perceived effects. Leaders and managers will be expected to be more integrated in a Nordic network and overall to see more impact on policy design and administrative reform patterns, while executive officers will be expected to score lower overall on Nordic network connections and on effects related to policy design and administrative reforms.

The third structural variable used is 'formal tasks,' divided into three types-planning, organizational development, and (re)organization and coordination. We will expect civil servants formally working with coordinative tasks, planning and organizational development, and (re)organization tasks to be more strongly integrated into Nordic networks. We will also expect to see more significant effects on policy design and administrative reforms because their attention structure is biased towards these.

Finally, we would expect tight 'Nordic contact and participation patterns' to lead to stronger use of international models in policy-making and also to stronger perceived significance of different reform measures.

\section{Database}

The primary empirical data in this article consist of an online survey of civil servants in Norwegian ministries and central agencies conducted in 2016. All civil servants with at least one-year tenure, from executive officers to top civil servants in the ministries, and every third civil servant in the central agencies, randomly selected, were

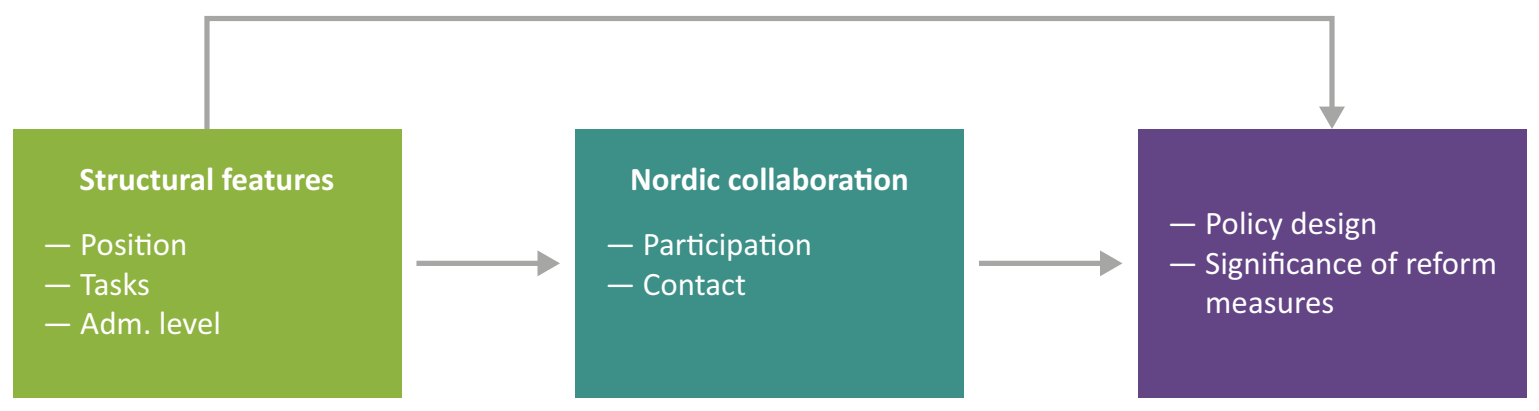

Figure 1. Research design. 
included. In total, 2,322 employees from the ministries and 1,963 from the central agencies answered the survey. The response rate was $60.1 \%$ in the ministries and $58.9 \%$ in the agencies, overall a very high response rate. It was a unique survey, representative of civil servants in the Norwegian central government. The survey has been conducted every 10 years since 1976 . Questions about Nordic collaboration and Nordic inspiration regarding policy design were included in earlier versions of the survey but the questions were not identical. Nevertheless, this gives some indication of change over time, which will be briefly referred to in the analyses.

The scope of Nordic collaboration is covered by two variables recording the civil servants' contact and participation patterns. Regarding participation, the following question was asked: 'Have you participated in a Nordic committee, working group or similar in the last year?'

Regarding contact, the following question was asked: 'How often do you estimate that you have had contact with Nordic governmental collaborative bodies over the last year?'

For both questions the respondents could choose between three categories: a) yes, several times, b) yes, once and c) no.

Regarding policy design the following question was asked: 'How often does it happen in your field of work that models are borrowed from other countries and/or international organizations when new measures or tasks are prepared?' The respondents could answer on a 5-point scale from 1) 'very often' to 5) 'very seldom/never.'

Regarding administrative reform measures, the following question was asked: 'A number of reforms and measures have been launched in conjunction with modernization and renewal work in government. How significant have the following reforms/measures been in your field of work?' On this set of questions, addressing fourteen different reform measures, the respondents could answer on a 5-point scale from 1) 'very significant' to 5) 'very insignificant/not used at all' and 'not relevant.'

The internal structural variables include administrative level, hierarchical position, and tasks. Regarding administrative level, we distinguish between ministries (1) and central agencies (2). Position varies from low, meaning executive officers and advisors, to middle managers and top civil servants. The tasks variable concerns whether organizational development and (re)organization or planning and coordination is a main task or not.

\section{The Scope of Nordic Cooperation}

About one third of the civil servants in Norwegian central government have contact with Nordic collaborative governmental bodies annually (Table 1). Mostly, these contacts have occurred a few times during the last year. This type of contact is more frequent than participation in a Nordic committee or working group. $17 \%$ report that they have done this during the last year. About half of respondents reported several such meetings. The correlation between participation and contact is statistically significant (Pearson $\mathrm{R}=.48^{* *}$ ). For ministerial civil servants contact with Nordic collaborative bodies is at the same level as with the European Commission, and for civil servants in central agencies it is at the same level as with EU agencies, although overall it is lower than with authorities in other countries altogether (Christensen, Egeberg, et al., 2018, p. 103). Contact with Nordic collaborative government bodies has remained at a rather stable level over the past 20 years. Participation in Nordic collaborative bodies is higher than in EU committees, but lower than in committees and working groups in other international government organizations. Over time, there has been a decrease in participation in Nordic committees and working groups among the civil servants (Christensen, Egeberg, et al., 2018, p. 104). In a survey of civil service bodies in $1998,40 \%$ of the Norwegian authorities in ministries and central agencies reported that they participated annually in Nordic committee, project-or working groups and $27 \%$ had monthly or more frequent contact with authorities in other Nordic countries in connection with EU/EEA-related work (Larsen, 2001).

\section{The Drivers of Nordic Cooperation}

The scope of Nordic participation and contact varies to a great extent with structural features, such as administrative level, position, and main tasks (Table 2). It is more common among civil servants in management positions than among executive officers as well as among those who have planning or coordination as a main task. Somewhat surprisingly, Nordic collaboration is less common among those who have organizational development or reorganization as a main task, indicating that Nordic collaboration might be more linked to policy design than to administrative reforms and that having main tasks linked to organizational development and reorganization has mainly an internal organizational focus. The importance of structural factors is similar for both participa-

Table 1. Participation in and contact with Nordic public bodies among civil servants in Norwegian central government over the past year (2016, percentages).

\begin{tabular}{lllr}
\hline & Yes & No & $\mathrm{N}=100 \%$ \\
\hline Participated in a Nordic committee or working group & 17 & 83 & 3,183 \\
Contact with a Nordic collaborative governmental body & 32 & 68 & 3,182 \\
\hline
\end{tabular}


Table 2. Variations among civil servants in Norwegian central government in participation in and contact with Nordic bodies (2016).

\begin{tabular}{lcr}
\hline & Participation & Contact \\
\hline Administrative level & $-.08^{* * *}$ & $.06^{* *}$ \\
Position & $-.10^{* * *}$ & $-.15^{* * *}$ \\
Main task & & $-.04^{* *}$ \\
- Organizational development/reorganization & $-.05^{* * *}$ & $.05^{* * *}$ \\
- Planning & $.06^{* *}$ & $.08^{* * *}$ \\
- Coordination & $.06^{* * *}$ & .04 \\
$R 2$ & .03 & .04 \\
$R 2$ scared & .02 & 28.340 \\
$F$ & 15.799 & .000 \\
Significance & .000 & .000 \\
\hline
\end{tabular}

Notes: Linear regression and standardized Beta coefficients. ${ }^{* *}=$ significant at $.01 * * *=$ significant at .001 .

tion and contact. The only difference is that civil servants in ministries have more contact than those working in central agencies, while the relationship is the other way around for participation in committees and working groups.

\section{The Perceived Effects of Nordic Cooperation on Policy Design and Administrative Reforms}

Regarding policy design, $43 \%$ of Norwegian civil servants often look to other countries for inspiration and role models when new measures and tasks are prepared. Only $9 \%$ say that this happens very seldom or never. So external influence plays quite a big role in policy design. The Nordic countries themselves are at the top of the list of model countries (Jacobsson et al., 2004). And such inspiration obviously goes both ways. For Swedish central government bodies, Finland and Norway were at the top of the list in 2019 regarding inspiration from other countries, followed by Denmark. Over time, Finland has become the most important collabora- tion partner, which probably has more to do with EU integration than with Nordic collaboration. One indicator of this is the EU PISA studies, which revealed that Finland differs from the other Nordic countries in pupils' school performance. In 1998, 21\% of Swedish agencies said that they often got inspiration from other Nordic countries; by 2019 , this had increased to $34 \%$. The highest numbers were in the field of business, culture, and environment (Jacobsson \& Sundstrøm, 2020). Thus, we can conclude that Nordic collaboration is still important for the Nordic countries.

We also see that participation in Nordic committees and working groups as well as contact with Nordic collaborative government bodies increases the changes that international role models will be used in policymaking (Table 3). Structural features, such as position and tasks, also matter. Civil servants in management positions and those working with planning and coordination as a main task more often look for inspiration and role models abroad when new policy measures and tasks are prepared. This is also to some extent the

Table 3. Inspiration and role models from external countries or international organizations for policy design among civil servants in Norwegian central government measures by Nordic contact and participation pattern and structural features.

\begin{tabular}{lc}
\hline & Inspiration from international models \\
\hline Participation in Nordic committees/working groups & $.13^{* * *}$ \\
Contact with Nordic collaborative government bodies & $.12^{* * *}$ \\
Administrative level & .01 \\
Position & $-.08^{* * *}$ \\
Main task & $.04^{*}$ \\
- Organizational development/reorganization & $.15^{* * *}$ \\
- Planning & $.07^{* * *}$ \\
- Coordination & .10 \\
$R 2$ & .08 \\
R2 scared & 40.022 \\
Significance & .000 \\
\hline
\end{tabular}

Notes: Linear regression and standardized Beta coefficients. ${ }^{*}=$ significant at $0.05 ;{ }^{* *}=$ significant at .001. 
case for those working with organizational development and reorganization.

When it comes to administrative reform means and measures, most of the listed means and measures are seen by civil servants as relevant in their own field of work. Digitalization, agency management, goal formulation, and transparency are ranked as the most significant, followed by coordination, risk management and evaluation, control, and monitoring. This picture is pretty similar to the one revealed in a survey of top civil servants in the Nordic countries in 2012-2014 (Lægreid \& Rykkja, 2016, p. 115). The pattern is rather similar across the Nordic countries. However, Nordic participation and contact does not have a significant effect on the perceived importance of most means and measures, such as form of affiliation, red tape, flexibility, evaluation and control, value-based management, risk management, digitalization, contracting out, agency management and goal specification.

Table 4 shows that there are some effects on perceptions of public-private partnerships, evidence-based policy making, role separations, transparency, and coordination, especially when it comes to contact with Nordic collaborative bodies. Participation in Nordic committees and working groups does not seem to be of great importance. The table also shows that structural patterns, such as administrative level, position and having planning or coordination as a main task, also matter. But the main picture is that these factors can only explain a small part of the variations in the perceptions of these reform means and measures.

\section{Discussion: Revisiting the Structural Perspective}

This analysis has, first, revealed that Norwegian civil servants are very well integrated into a Nordic network of participation and contact. Contact with Nordic collabo- rative government bodies is more frequent than active participation in Nordic collegial bodies. The contact pattern has been rather stable over the past 20 years, but there has been a decrease in participation in Nordic committees and working groups. Overall, there has been no significant disintegration of the Nordic administrative collaborative network despite stronger integration in the EU. The intensity of the collaboration is slightly weaker, however, as illustrated by less frequent participation in Nordic collaborative bodies. Thus, there seems to be a differentiated integration that still allows for a Nordic administrative space.

Second, the Nordic collaborative network is also differentiated. It varies to a great extent with the civil servants' organizational affiliation, position, and main tasks. Civil servants who are in leadership positions in ministries and who have planning and coordination as main tasks are more integrated into a Nordic contact pattern. The same goes for participation in project-and working groups for those working in central agencies.

Third, the effect of Nordic collaboration is stronger on policy design than on administrative reform means and measures. Civil servants with a Nordic collaborative network are more inspired by international role models than those without such a network. However, Nordic collaboration plays a less significant role when it comes to specific administrative reforms. Several reform measures are not affected by Nordic collaboration, and for those that are, contact patterns are more important than participation patterns. When it comes to publicprivate partnership, separation of roles, transparency, and coordination, Nordic contact plays a significant role. Increased Nordic contact seems to stimulate such reform measures.

Fourth, internal structural features such as tasks, administrative position, and administrative level also matter for some of the reform measures. Having planning

Table 4. The perceived significance of different administrative tools and measures among civil servants in Norwegian central government by Nordic contact and participation pattern and structural features. Linear regression.

\begin{tabular}{|c|c|c|c|c|c|}
\hline & $\begin{array}{l}\text { Public-private } \\
\text { partnership }\end{array}$ & $\begin{array}{c}\text { Evidence based } \\
\text { policymaking }\end{array}$ & Role separation & Transparency & Coordination \\
\hline Nordic participation & .01 & $.05^{*}$ & .00 & -.02 & .00 \\
\hline Nordic contact & $.10 * * *$ & .04 & $.06 *$ & $.08^{* *}$ & $.05^{*}$ \\
\hline Administrative level & $-.08 * *$ & $.07 * *$ & -.02 & -.03 & .01 \\
\hline Position & .01 & $-.07^{* *}$ & -.02 & $-.05^{*}$ & -.03 \\
\hline \multicolumn{6}{|l|}{ Main task: } \\
\hline - OD/reorganization & .01 & .03 & .04 & .00 & .04 \\
\hline - Planning & .03 & $.08 * * *$ & $.08 * *$ & -.02 & $.05 *$ \\
\hline - Coordination & .03 & $.06 * *$ & .05 & .01 & $.07^{* *}$ \\
\hline$R 2$ & .02 & .03 & .01 & .01 & .01 \\
\hline R2 scared & .02 & .02 & .01 & .01 & .01 \\
\hline$F$ & 5.324 & 8.285 & 3.463 & 3.471 & 3.364 \\
\hline Significance & .000 & .000 & .001 & .001 & .000 \\
\hline
\end{tabular}

Notes: Standardized Beta coefficients. ${ }^{*}=$ significant at $.05 ;{ }^{* *}=$ significant at at $01 ;{ }^{* *}=$ significant at .001. 
and coordination as a main task seems to play a role for the importance of means and measures related to evidence-based policy making, role separation and collaboration. Civil servants in ministries are less focused on public-private partnerships and more on evidence-based policy-making compared with those working in central agencies. Evidence-based policy-making and transparency are also more prominent in ministries than in central agencies.

There might also be indirect effects. We have shown in Table 2 that Nordic contact and participation patterns can be predicted by structural factors. When in Table 3 and 4 we add Nordic contact and participation patterns in addition to structural factors as predictors of international policy inspiration and for the significance of different reform tools, the structural factors might also have an additional indirect effect on policy inspiration and use of reform tools through Nordic communication and participation patterns.

Summing up, the findings give some support to the structural perspective. We find, first, that the scope and intensity of the Nordic contact pattern varies according to the organizational affiliation, position, and main tasks of the civil servants. Second, inspiration from international role models seems to be affected by Nordic collaboration as well as by internal structural features. Third, there are also some effects of Nordic contact patterns as well as of administrative position, organizational affiliation, and task structure in the central bureaucracy on the civil servants' perceived significance of some reform means and measures. However, the effects of Nordic collaboration are weaker on administrative reform measures than on policy design.

\section{Conclusion}

Taken together, the qualitative data, secondary data and the survey data collected for this article show that Nordic administrative collaboration can best be seen as differentiated integration. A common Nordic administrative space exists and exhibits some distinct features that distinguish it from other European administrative families, even if there also are some similarities with non-Nordic countries (Greve et al., 2016). When it comes to policy design and administrative reforms in the Nordic countries, there is also variation across them with respect to policy areas, tasks, administrative levels, and positions. Overall, the picture is characterized by syncretism, combining existing and new administrative arrangements in an adaptive and agile way (Ansell, Trondal, \& Øgård, 2017; Greve et al., 2019).

We conclude that Nordic cooperation has evidently not collapsed with more integration of the Nordic countries into the EU. Even if participation in Nordic central government bodies might have been reduced somewhat, contact is still rather frequent. The Norwegian civil servants still look to their colleagues in neighbouring Nordic countries for inspiration regarding policy design as well as administrative reforms. In particular, Norway seems to collaborate closely with Sweden and Denmark. Also, for Swedish central government bodies there has been no decline in Nordic administrative collaboration (Jacobsson \& Sundstrøm, 2020). As far as our data go, they indicate that Nordic administrative collaboration is still 'alive and kicking.' It has been affected by, but not marginalized, by increased European and international integration.

The main picture is, however, that Nordic countries' copying policies and administrative reform measures from each other is not a simple and straightforward process. Domestic policy design and administrative reforms are not simply taken on board as a blueprint of what is going on in neighbouring countries. The timing, pace, and intensity of the reforms vary across countries, and there are more similarities in general reform and policy ideas than in specific policy design and reform means and measures. Rather than copying arrangements through simple diffusion there is an editing and translation process going on in which the general reform ideas are modified and adapted to the specific domestic traditions and situations as they move from one Nordic country to another (Greve et al., 2019). The external Nordic administrative collaboration pattern matters, but so do internal structural characteristics.

This study has some limitations. First, the data base has a bias towards cross-sectional data. More longitudinal data would have strengthened the empirical description. Second, the data base has a Norwegian bias, and more data from the other Nordic countries would have strengthened the findings. Third, the data on international inspiration in policy-making is not specifically linked to the Nordic countries, which might weaken the proxy of this variable.

Going back to our more specific research questions, we can, first, conclude that the scope of Nordic administrative collaboration among Norwegian civil servants in central government is rather broad, especially when it comes to contact with Nordic governmental collaborative bodies but also when it comes to deriving inspiration and ideas for administrative and policy reforms. Second, this collaborative pattern varies significantly with internal structural features, such as administrative affiliation, position, and main tasks. Third, we see that Nordic collaboration is perceived to influence policy design more than on specific administrative reform means and measures. Fourth, we see that internal structural features also matter when it comes to explaining variations in how civil servants are inspired by external models in policy design and in the perceived significance of specific reform measures.

\section{Acknowledgments}

We would like to thank Tom Christensen, Morten Egeberg, and Jarle Trondal for collaboration on the Norwegian Administrative survey. We also thank the 
European Community's Seventh Framework Programme under Grant Agreement no. 266887 for support and the EU funded project Coordinating for Cohesion in the Public Sector of the Future (COCOPS) for some of the data used.

\section{Conflict of Interests}

The authors declare no conflict of interests.

\section{References}

Ansell, C., Trondal, J., \& Øgård, M. (Eds.). (2017). Governance in turbulent times. Oxford: Oxford University Press.

Bauer, M. W., \& Trondal, J. (Eds.). (2015). The Palgrave handbook of European administrative system. Houndsmills: Palgrave Macmillan.

Bjørklund, A., Clark, M. A., Edin, P. A., Fredriksson, P., \& Krueger, A. B. (Eds.). (2005). The market comes to education in Sweden. New York, NY: Russel and Sage.

Bjurstrøm, K. H., \& Christensen, T. (2017). Government institutions and state reforms. In O. Knutsen (Ed.), The Nordic models in political science (pp. 149-170). Bergen: Fagbokforlaget.

Bleiklie, I., \& Michelsen, S. (2019). Scandinavian higher education governance: Pursuing similar goals through different organizational arrangements. European Policy Analysis, 5(2), 190-209.

Brunsson, N., \& Olsen, J. P. (1993). The reforming organization. London: Routledge.

Christensen, T., Egeberg, M., Lægreid, P., \& Trondal, J. (2018). Sentralforvaltningen: Stabilitet og endring gjennom 40 år [The central government: 40 years of stability and change]. Oslo: Universitetsforlaget.

Christensen, T., Gornitzka, Å., \& Maassen, P. (2014). Global pressure and national culture: A Nordic university template? In P. Mattei (Ed.), University adaptation at difficult economic times (pp. 30-52). Oxford: Oxford University Press.

Christensen, T., \& Lægreid, P. (in press). Performance management: Experiences and challenges. In B. Hildreth, E. Lindquist, \& J. Miller (Eds.), The Routledge handbook of public administration (4th ed.). London: Routledge.

Christensen, T., \& Lægreid, P. (Eds.). (2007). Transcending New Public Management: Transformation of public sector reforms. Aldershot: Ashgate.

Christensen, T., \& Lægreid, P. (2020). Balancing governance capacity and legitimacy: How the Norwegian government handled the COVID-19 crisis as a high performer. Public Administration Review. https://doi. org/10.1111/puar.13241

Christensen, T., Lægreid, P., \& Røvik, K. A. (2020). Organization theory and the public sector ( 2 nd ed.). London: Routledge.

Christensen, T., Lægreid, P., \& Rykkja, L. H. (2018). Reforming the Norwegian police between structure and culture: Community police or emergency police. Public Policy and Administration, 33(3), 241-259.

Egeberg, M. (2012). How bureaucratic structure matters: An organizational perspective. In B. G. Peters \& J. Pierre (Eds.), The SAGE handbook of public administration (pp. 157-168). London: Sage.

Egeberg, M., \& Trondal, J. (2018). An organizational approach to public governance. Oxford: Oxford University Press.

Ejersbo, N., Greve, C., Lægreid, P., \& Rykkja, L. H. (2017). Er det en særlig nordisk reformmodel for styringsreformer? [Is it a specific Nordic reform model for governance reforms?]. In E. M. Ghin, C. H. Grøn, \& M. B. Kristiansen (Eds.), Styring og evaluering i den offentlige sector [Governance and evaluation in the public sector] (pp. 55-76). Copenhagen: Hans Reitzels Forlag.

Elvbakken, K. T., \& Hansen, H. F. (2019). Evidence producing organizations: Organizational translation of travelling evaluation ideas. Evaluation, 25(3), 261-276.

Elvbakken, K. T., Lægreid, P., \& Rykkja, L. H. (2008). Regulation for safe food: A comparison of five European countries. Scandinavian Political Studies, 31(2), 125-148.

Greve, C., Ejersbo, N., Lægreid, P., \& Rykkja, L. H. (2019). Unpacking Nordic administrative reforms: Agile and adaptive governments. International Journal of Public Administration, 43(8), 697-710.

Greve, C., Lægreid, P., \& Rykkja, L. H. (Eds.). (2016). Nordic administrative reforms: Lessons for public management London: Palgrave Macmillan.

Greve, C., Lægreid, P., \& Rykkja, L. H. (2018). Nordic bureaucracy beyond new public management. In $\mathrm{H}$. Byrkjeflot \& F. Engelstad (Eds.), Bureaucracy and society in transition (Vol. 33, pp. 205-224). Bingley: Emerald Publishing.

Hammerschmid, G., Stimac, V., \& Wegrich, K. (2014). Management capacity and performance in European public administration. In M. Lodge \& K. Wegrich (Eds), The problem-solving capacity of the modern state (pp. 105-126). Oxford: Oxford University Press.

Hansen, H. F. (2010). Educational evaluation in Scandinavian countries: Converging or diverging practices. Scandinavian Journal of Educational Research, 53(1), 71-87.

Hansen, H. F. (2011). NPM in Scandinavia. In T. Christensen \& P. Lægreid (Eds.), The Ashgate research companion to new public management (pp. 113-130). Burlington: Ashgate.

Helgøy, I., \& Homme, A. (2007). Towards a new professionalism in school? A comparative study of teacher autonomy in Norway and Sweden. European Educational Journal, 6(3), 232-248.

Jacobsson, B., Lægreid, P., \& Pedersen, O. K. (Eds.). (2001). Europaveje. EU i de nordiske sentralforvaltninger [Roads to Europe: The EU in the Nordic central governments]. København: DJ $\varnothing \mathrm{F}$.

Jacobsson, B., Lægreid, P., \& Pedersen, O. K. (2004). Eu- 
ropeanization and transnational states: Comparing Nordic central governments. London: Routledge.

Jacobsson, B., \& Sundstrøm, G. (2020). Tjugofem år av gemenskap: Statsforvaltningen och Europeiska Unionen [Twenty-five years of community: Central government and the European Union] (Report No. 3). Stockholm: Sieps.

Johnsen, Å., \& Vakkuri, J. (2006). Is there a Nordic perspective on public sector performance management? Financial Accountability \& Management, 22(3), 291-308.

Kassim, H., Wright, V., \& Peters, G. P. (Eds). (2000). The national coordination of EU policy: The domestic level. Oxford: Oxford University Press.

Knill, C. (2001). The Europeanisation of national administrations. Cambridge: Cambridge University Press.

Knutsen, O. (Ed). (2017). The Nordic models in political science: Challenged but still viable? Bergen: Fagbokforlaget.

Kristiansen, M. B. (2015). Management by objectives and results in the Nordic countries: Continuity and change, differences and similarities. Public Performance and Management Review, 38, 542-569.

Lægreid, P. (2017). Nordic administrative traditions. In P. Nedergaard \& A. Wivel (Eds.), The Routledge handbook on Scandinavian politics (pp. 80-91). London: Routledge.

Lægreid, P., \& Pedersen, O. K. (Eds.). (1994). Forvaltningspolitikk i Norden [Nordic administrative policies]. Copenhagen: Jurist-og $\varnothing$ konomforbundets Forlag.

Lægreid, P., Randma-Liiv, T., Rykkja, L. H., \& Sarapuu, K. (2016). Coordination challenges and administrative reforms. In G. Hammerschmid, S. Van de Walle, R. Andrews, \& P. Bezes (Eds.), Public administration reforms in Europe: The view from the top (pp. 244-258). Cheltenham: Edward Elgar.

Lægreid, P., Roness, P. G., \& Rubecksen, K. (2006). Performance management in practice: The Norwegian way. Financial Accountability and Management, 22(3), 251-270.

Lægreid, P., \& Rykkja, L. H. (2016). Administrative reforms: Processes, trends and content. In C. Greve, P. Lægreid, \& L. H. Rykkja (Eds.), Nordic administrative reforms: Lessons for public management (pp. 105-228). London: Palgrave Macmillan.

Larsen, G. (2001). Nordiske og internasjonale relasjoner [Nordic and International Relations]. In B. Jacobsson, P. Lægreid, \& O. K. Pedersen (Eds.), Europaveje: EU i de Nordiske sentralforvaltninger [Roads to Europe: The EU in Nordic central governments] (pp. 159-190). Copenhagen: Jurist-og $\varnothing$ konomforbundets forlag.

Leruth, B., Gänzle, S., \& Trondal, J. (2019). Exploring differentiated disintegration in a post-Brexit European Union. Journal of Common Market Studies, 57(5), 1013-1030.

March, J. G., \& Olsen, J. P. (1989). Rediscovering institutions. New York, NY: The Free Press.

Meyer-Sahling, J.-H., \& Yesilkagit, K. (2011). Differential legacy effects: Three propositions on the impact of administrative traditions on public management reform in Europe East and West. Journal of European Public Policy, 18(2), 311-322.

Öberg, S. A., \& Wockelberg, H. (2016). Nordic administrative heritages and contemporary institutional design. In C. Greve, P. Lægreid, \& L. H. Rykkja (Eds.), Nordic administrative reforms: Lessons for public management (pp. 57-78). London: Palgrave Macmillan.

Olsen, J. P. (2003). Towards a European administrative space. Journal of European Public Policy, 10(4), 506-531.

Olsen, J. P. (2010). Governing through institution building. Oxford: Oxford University Press.

Olsen, J. P., \& Sverdrup, B. O. (Eds.). (1998). Europa i Norden: Europeisering av nordisk samarbeid [Europe in the Nordic countries: Europeanization of the Nordic cooperation]. Oslo: Tano Aschehoug.

Pollitt, C., \& Bouckaert, G. (2017). Public management reform (4th ed.). Oxford: Oxford University Press.

Schimmelfenning, F., Leuffen, D., \& Ritterberger, B. (2015). The European Union as a system of differentiated integration: Interdependence, politization and differentiation. Journal of European Public Policy, 22(6), 764-782.

Simon, H. (1958). Administrative behavior. New York, NY: Macmillan. vStreeck, W., \& Thelen, K. (2005). Beyond continuity. Oxford: Oxford University Press.

Sundstrøm, G. (2015). Administrative reform. In J. Pierre (Ed.), The Oxford handbook of Swedish politics (pp. 315-331). Oxford: Oxford University Press.

Trondal, J., \& Peters, B. G. (2013). The rise of European administrative space. Journal of European Public Policy, 20(2), 295-307.

Wegrich, K., \& Stimac, V. (2014). Coordination capacity. In M. Lodge \& K. Wegrich (Eds.), The problem-solving capacity of the modern state (pp. 41-62). Oxford: Oxford University Press.

\section{About the Authors}

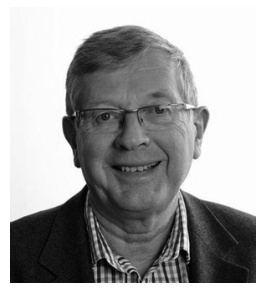

Per Lægreid is Professor Emeritus at the Department of Administration and Organization Theory, University of Bergen, Norway. He has published extensively in international journals on public sector reform, public management policy, institutional change and crisis management from a comparative perspective. His latest books include Societal Security and Crisis Management: Governance Capacity and Legitimacy (co-edited with L. H. Rykkja, Palgrave Macmillan, 2019). and Organization Theory and the Public Sector: Instrument, Culture and Myth (with T. Christensen and K. A. Røvik, Routledge, 2020). 
Lise H. Rykkja is Professor at the Department of Administration and Organization Theory, University of Bergen. Her research concentrates on public administration from an institutional and comparative perspective and focuses on administrative reforms, public management, collaboration, crisis management and public security. Her latest publications include articles in Public Administration, Public Administration Review, Public Management Review, Studies in Conflict \& Terrorism and Risk, Hazards \& Crisis in Public Policy. Rykkja currently leads the Horizon 2020 project 'Transforming into Open, Innovative and Collaborative Governments' (TROPICO). 